\title{
Editorial Note: Advances in Computational Intelligence for Multimodal Biomedical Imaging
}

Published online: 14 December 2018

(C) Springer Science+Business Media, LLC, part of Springer Nature 2018

Multimedia Tools and Applications gratefully acknowledges the editorial work of the scholars listed below on the special issue entitled, "Advances in Computational Intelligence for Multimodal Biomedical Imaging."

Of 45 papers submitted to this issue, 19 were eventually accepted after a stringent peer-review process.

\section{Mohammed El Hassouni (Corresponding Guest Editor)}

Mohammed V University in Rabat, Morocco

mohammed.elhassouni@um5.ac.ma

\section{Rachid Jennane}

University of Orleans, France

Rachid.Jennane@univ-orleans.fr

\section{Ahmed Ben Hamida}

University of Sfax, Tunisia

Ahmed.Benhamida@enis.rnu.tn

\section{Habib Benali}

Concordia University, Canada

habib.benali@concordia.ca

\section{Basel Solaiman}

Telecom Bretagne, Brest, France

Basel.Solaiman@telecom-bretagne.eu

Publisher's Note Springer Nature remains neutral with regard to jurisdictional claims in published maps and institutional affiliations. 